Motor cars also consume a phenomenal amount of space and within Los Angeles, for example, account for no less than two thirds of that huge city's land area being given up to motorways, other roads, and areas for parking. In many parts of the world the car also dictates overall urban planning and transport policies in favour of the car owner. Thus in terms of recreation facilities and shops offering cheap and healthy foods the choice offered to the car owner is usually much greater than that offered to households without cars (in Britain two fifths of the total).

The crucial paradigm is the currently unstable relation between population, health, and a sustainable environment. One implication of the instability is that a new approach to equity between the developed and developing world is urgently needed so that wealth currently lost in waste and over consumption can in future be invested to reduce poverty and ignorance. Furthermore, from now on new development policies must be assessed for their impact on health as well as the environment. The achievement of these aims will require major changes in the attitudes of people as well as of governments.

At all levels the health professions in their traditional role as advocates and agents for both private and public health have a key part to play in drawing attention to the serious threat to global health occasioned by a growing "energy hungry and throwaway society."

Visiting Professor in International Health,

DONALD ACHESON

London School of Hygiene and Tropical Medicine,

London WCIE 7HT

1 Chadwick E. 1842 The sanitary condition of the labouring population of Great Britain. Edinburgh: Edinburgh University Press, 1965.

Simon J. The medical officer of the privy council. Report 1858. London: HMSO, 1859.

3 World Commission on Environment and Development. Our common future. Oxford: Oxford University Press, 1987. (Brundtland Commission's report.)

4 World Health Organisation. Implementation of the global strategy for health for all by the year 2000 Geneva: WHO, 1992. (Eighth report in world health situation paper for provisional agenda of 45 th world health assembly, item 17.)

\title{
A meeting of rich and poor
}

\section{Poverty and environmental destruction are linked and must matter to us all}

The ideological divide between East and West has ended, and the major split in the world now is between rich and poor. Last week the World Bank warned that world poverty is increasing and pointed out its intimate link with environmental destruction. ' "Alleviating poverty," said the bank, "is a moral imperative and a prerequisite for environmental sustainability." The bank, whose record on alleviating poverty has not always been admirable, now estimates that $\$ 75$ billion a year will be needed by 2000 to carry out essential programmes on water and sanitation, electric power, road transport, carbon dioxide emissions, agriculture, population, and female education.

It looks increasingly as if world survival will depend on the rich not only meeting the costs of environmental improvements but also shifting resources to the developing world. But the early signs on next month's "earth summit" in Rio de Janeiro are that the rich and poor are squabbling. ${ }^{2}$ President Bush has finally been persuaded to attend but has suggested that he will agree to nothing that will harm the United States economy in the short term for fear that he will not be reelected. This is a wholly inadequate response. The dialectic of democracy, said one of Mr Bush's predecessors, Thomas Jefferson, is the unremitting conflict between the hopes of the many and the interests of the few. The world desperately needs rich and poor to get together, and it must be for the rich - with their power and resources - to take the lead.

The rich and poor confront each other most starkly over Third World debt, and Dorothy Logie explores the problem on $\mathrm{p} 1423$. In 1990 the developing countries received $£ 28 \cdot 3$ billion in aid but had to pay back $£ 34.5 \mathrm{~m}$ in interest on their debts. ${ }^{3}$ That year every man, woman, and child from the poor world had to pay the rich world $£ 17.40 .^{4}$ In several countries debt exceeded gross national product. ${ }^{5}$ Poverty and hunger have increased, the quality of water supplies and educational and health services has fallen - and, as a direct consequence of debt, estimates Unicef, half a million children die each year. ${ }^{6}$

The debt crisis grew out of the oil crisis of the '70s. Commercial banks were flooded with "petrodollars" and were desperate to lend them. They encouraged the bigger economies in the developing world (Mexico and Nigeria, for instance) to take out large loans, while the multilateral financial institutions-like the World Bank and the International Monetary Fund-lent money to the poorer countries. Little of this money was spent on social and economic development. Much of it went on arms, as Anthony Zwi and Anthony Ugalde discuss on p 1421: in 1986 developing countries spent more on arms than they received in aid. ${ }^{7}$ The average per capita expenditure on arms in the developing world is $\$ 38$ compared with $\$ 12$ on health, and world expenditure on arms is of the same order as the total Third World debt - currently $\$ 1.4$ trillion. $^{7}$

From the beginning the poor countries had to divert resources to feed their debt, but the crunch came in 1980 when the United States government forced up world interest rates. Interest payments soared, commodity prices plummeted, and the economies of many developing countries shrank rather than grew: the overall result was what the Economist has called a lost decade for the poor countries. ${ }^{8}$ The rich countries were initially completely unwilling to release the poor countries from their debts, and the economic crises quickly translated into increased death rates among children and a collapse in education and other services. ${ }^{49}$ In most countries the International Monetary Fund insisted on cuts in public spending, increases in the price of public utilities like water and power, the abolition of consumer subsidies (so raising the price of basic foods), and reductions in real wages. Average incomes fell by $20 \%$ in sub-Saharan Africa and by $10 \%$ in Latin America during the ' 80 s, while the price of basic foods trebled or increased even more. ${ }^{10}$ In the 37 poorest countries in the world per capita expenditure on education fell by a quarter, and in a fifth of developing countries numbers of primary school students are declining. ${ }^{\text {" }}$ Yet, as the World Bank reminded us last week, spending money on the education of girls and women is probably the single most cost effective way of encouraging development and raising health standards. ${ }^{1}$

As the Economist has said, "Throughout history debt crises have been resolved by partial write-offs of debts." 12 Yet the rich countries and their banks have been slow to do this. In 
1989 the American Brady plan encouraged the swapping of debt for equity, and in 1990 John Major (then chancellor of the exchequer) produced the Trinidad plan, which has led to some rich countries writing off debts of the poorest countries. But the debt crisis is far from resolved and will hang over the Rio summit. The Economist has suggested that mandating commercial banks to write off the debts might actually appeal to the banks because they know that they will never get much of the money back and their main anxiety is that they will suffer competitively if they unilaterally write off debts. ${ }^{12}$

Third World debt and poverty must matter to those in rich countries-not only because having almost two billion without enough to eat and clean water to drink is wrong but also because poverty is tied up so closely with destruction of the environment. As the World Bank explained last week, poverty leads to population growth, air pollution, desertification, and soil degradation." "The state of their economies," said the Financial Times, "gives the people [in poor countries] no choice but to destroy their natural endowments to survive."'13 The World Bank argues that economic development should lead to less pollution, but the effect on carbon dioxide emissions of a doubling of per capita coal consumption in China by 2000 (and greater increases are planned) would more than offset the United States ceasing to use coal at all. ${ }^{14}$ The earth summit cannot ignore poverty.

But what does all this mean to doctors? Poverty and the state of the environment together probably have more effect on health than anything else, but doctors may feel overwhelmed by the scale of the problem-most politicians are. But many doctors similarly felt overwhelmed by the threat of nuclear destruction; yet doctors played a central role in reducing the threat of nuclear war. We can do the same for world poverty and environmental destruction-through education of ourselves and others, research, campaigning, and individual and concerted action.

Editor, $B M \mathcal{F}$

RICHARD SMITH

Consultant Physician,

ROBIN STOTT

Lewisham Hospital,

London SE13 6LH

1 World Bank. Development and the environment. Washington: World Bank, 1992

2 Godlee F. Rio agrees to costly compromise. BMJ 1992;304:1329-30.

3 Gillen D. Decade of the disaster. BMF 1991;303:1017.

4 Christian Aid. Banking on the poor. London: Christian Aid, 1991.

5 George S. The debt boomerang: how Third World debt harms us all. London: Pluto Press, 1992.

6 Unicef. State of the world's children. Oxford: Oxford University Press, 1991.

7 Leger Sivard R. World military and social expenditures. Wrathingtess, 1991.

8 Distracted by debt: the developing countries' debt troubles have made the 1980 s the lost decade. Economist 1989 Sept 23.

Kanii N, Kanji N, Manji F. From development to sustained crisis-structural adjustment, equity, and health. Soc Sci Med 1991;33:985-93.

Clark J, Allison C. Zambia - debt and poverty. Oxford: Oxfam, 1989.

10 Clark J, Allison C. Zambia-debt and poverty. Oxford:

11 Unesco. Statistical yearbook. Paris: Unesco, 1989.

Survey of the IMF and the World Bank. And forgive us our debts-the lessons of the debt debacle are still being learned. Economist 1991 Oct 12

13 Development and the environment. Financial Times 1992 May 18:16.

14 Ehrlich PR, Ehrlich AH. The population explosion. New York: Simon and Schuster, 1990

\section{After Windscale (Sellafield)}

\section{Studies have increased our understanding of cluster analysis but not why clusters of childhood leukaemia occur}

The past decade has seen increasing concern in Britain about the possibility that exposure to a raised level of environmental radiation could lead to an increased risk of childhood leukaemia. This concern was initially fuelled by a well researched television programme testifying to the possibilities of clusters of cases of childhood leukaemia around British nuclear installations and followed by a plethora of reports from different parts of the country based on different statistical methods and geographical groups. Most suggested a possible increase in risk around installations, but overall the results were not clear cut and led to considerable confusion.

A recent publication on the geographical epidemiology of childhood leukaemia and non-Hodgkin's lymphomas in Great Britain, edited by Gerald Draper, ${ }^{1}$ is remarkable in that it has assembled contributions from nearly all the current major researchers in this country, with useful summaries and overview papers pulling together the results and discussing reasons for inconsistencies.

The results are based on 9411 patients born in Britain whose cancers were registered during 1969-83. The data are strengthened by the high quality and completeness of the registration of these childhood cancers, certainly for the more recent years.

Although the main findings amount to far less than a break through, they give us some clear and consistent leads for further research.

As in other Western countries, the lymphocytic and unspecified leukaemias had an annual incidence of 30 per million children aged under 15 and the pronounced and unexplained peak at the age of 2-3 years was confirmed. In contrast, the lymphomas have an overall incidence of 6 per million children, are rare before the age of 2 , and have a fairly constant rate thereafter. The existence of a geographical variation in incidence was confirmed, as was a small trend towards an increase with increasing socioeconomic status (better off children are more likely to get leukaemia).

Whether clusters exist ${ }^{2}$ (which raises the possibility of environmental causes) has been investigated with several independent statistical techniques. The conclusions are that geographical clusters of the leukaemias do occur, particularly among those aged $0-4$. There was some evidence that the early childhood peak was most pronounced in sparsely populated areas. Reference was made to the papers by Kinlen and colleagues,${ }^{34}$ which suggested that for young children recent population turnover predisposes to new exposure to viral diseases and that these, perhaps interacting with another hazardous exposure, may initiate the malignant process.

The presence of raised incidence near nuclear installations and other potentially polluting sources was confirmed, but several other districts with previously unrecognised high incidences were also found.

Some of the most important aspects of the report are its expqsition of problems relating to the reliability of estimates of the population in small areas, particularly between censuses and in places where there is considerable movement of the population. A need clearly exists to improve and make more contemporary local population estimates, as well as to continue to develop methods of investigating clusters which are independent of such data.

In addition stress is laid on the importance, in childhood leukaemias, of basing demographic and other investigations on the characteristics of the place of residence where the 